\title{
PENGARUH PEMETIKAN TUNAS TERHADAP HASIL PANEN UBI KAYU
}

\author{
Amina Hayoto ${ }^{1}$, Cornelia Pary ${ }^{2}$, Suhaedir Bachtiar ${ }^{3}$ \\ ${ }^{1,2}$ Program Studi Pendidikan Biologi IAIN Ambon \\ ${ }^{3}$ Guru IPA SMPN Batang Sulawesi Selatan \\ E-mail: aminahayoto@yahoo.co.id
}

\begin{abstract}
Abstrak: Jenis penelitian yang digunakan adalah eksperimen lapangan dengan menggunakan Rancangan Acak Kelompok (RAK) yang terdiri dari 4 perlakuan yaitu $\mathrm{X}_{0}$, $\mathrm{X}_{1}, \mathrm{X}_{2}$, dan $\mathrm{X}_{4}$. Tiap unit perlakuan terdiri dari 1 jenis ubi kayu yaitu dari varietas sawah. Waktu penelitian ini di laksanakan pada tanggal 9 Oktober sampai dengan 1 November 2014. Analisis data dalam penelitian ini yaitu menggunakan analisis varians (Anava). Jika ada pengaruh, maka dilanjutkan dengan menggunakan uji lanjut (BNT) berdasarkan nilai koefisien keragaman (KK). Hasil penelitian menunjukkan bahwa terapat pengaruh pemetikan tunas terhadap hasil panen ubi kayu, Hasil uji anava didapatkan bahwa $\mathrm{F}$ hitung $=5,12 \geq \mathrm{F}_{\text {tabel }}=2,262$, berarti terdapat pengaruh pemetikan tunas terhadap hasil panen ubi kayu atau $\mathrm{H}_{1}$ di terima dan $\mathrm{H}_{0}$ di tolak pada taraf signifikan $5 \%$ dan besar pengaruh pemetikan tunas terhadap hasil panen ubi kayu adalah $92 \%$.
\end{abstract}

\section{Kata Kunci: Pemetikan Tunas, Hasil Panen Ubi Kayu}

Pangan menjadi kebutuhan primer manusia yang tidak mengenal batasan, baik waktu, ruang maupun tingkatan sosial. Sejak manusia hidup pangan selalu menjadi kebutuhan mendasar manusia yang tidak bisa ditawar. Demikian juga dengan strata kehidupan manusia dari kalangan atas, menengah atau bawah tidak ada yang tidak membutuhkan pangan. Yang membedakan hanya permasalahan selera dan kebiasaan makan. Dengan kata lain pembicaraan tentang pangan tidak mengenal istilah usang atau akan selalu dibutuhkan, mengingat berkaitan dengan kebutuhan pokok dan kesehatan manusia.

Umumnya petani di pedesaan menanam ubi kayu baik yang ditanam di kebun maupun dipekarangan. Sebagaimana sudah diketahui sejak dulu bahwa peran ubi kayu sebagai penyangga sumber karbohidrat bagi kebanyakan masyarakat di pedesaan. Hal tersebut karena ubi kayu sebagai komoditas strategis untuk ketahanan pangan di pedesaan dan juga karena mudahnya menanam ubi kayu yang antara lain karena tidak perlunya perawatan khusus untuk menanam ubi kayu dan sampai sekarang masih tercatat tidak banyak serangan hama dan penyakit yang sangat merugikan. Kontradiksi terhadap nilai lebih ini, menjadikan ubi kayu bukan dijadikan sebagai tanaman utama melainkan tanaman kedua atau tanaman celah (Rukmana, 2001).

Komoditi ubi kayu merupakan komoditi tanaman pangan yang penting di Indonesia setelah padi, jagung, kedelai, kacang tanah dan kacang hijau, yaitu sebagai bahan pangan, pakan dan bahan baku industri baik hulu maupun hilir. Disamping itu 
komoditi tersebut merupakan tanaman dengan daya adaptasi yang luas, mudah disimpan, mempunyai rasa enak sehingga dapat membuka lapangan pekerjaan dan meningkatkan pendapatan petani beserta keluarganya. Komoditi ubi kayu selain berperan untuk memenuhi kebutuhan sumber karbohidrat untuk substitusi beras, juga sebagai bahan untuk diversifikasi pangan. Ubi kayu juga dapat dimanfaatkan sebagai sumber pakan, bahan baku industri dan bahan baku bioethanol (Soekartawi, 2005).

Dalam upaya peningkatan produksi ubi kayu, perlu dikombinasikan beberapa faktor produksi, baik secara botanis maupun ekologis, adaptasi dan agronomis. Dengan demikian produksi ubi kayu dapat ditingkatkan, bukan saja sebagai pemenuh kebutuhan karbohidrat/pangan tetapi juga pemenuh kebutuhan industry (Anonim, 2004). Upaya ini akan berhasil apabila petani sebagai produsen dalam pelaksanaannya mau meninggalkan cara budidaya tradisional dan menerapkan cara budidaya yang dianjurkan, seperti pengolahan tanah yang baik, menggunakan varietas unggul, pemilihan bahan tanam yang tepat, pengaturan jarak tanam yang tepat, pemupukan serta penyiangan dan pertumbuhan (Purwono \& Purnamawati, 2007).

Sampai saat ini sektor pertanian umumnya di daerah Maluku belum dapat mensejahterakan petani, dan memenuhi kebutuhan sendiri, dikarenakan peran ubi kayu dalam perekonomian nasionalkhususnya Maluku terus menurun karena dianggap bukan komoditas prioritas sehingga kurang mendapat dukungan investasi baik dari sisi penelitian dan pengembangan, penyuluhan, pengadaan sarana dan prasarana, serta dalam pengaturan dan pelayanan. Akibatnya luas areal panen ubi kayu terus berkurang dikarenakan sebagian besar petani ubi kayu beralih profesi atau dengan kata lain mengganti tanaman ubi kayu dengan tanaman lain yang dianggap lebih bermanfaat, sehingga produktivitas ubi kayu tidak meningkat secara nyata. Salah satunya penyebabnya adalah belum tepatnya teknologi untuk meningkatkan pendapatan petani ubi kayu. Hal ini dikarenakan sumberdaya alam dan sumberdaya manusia belum dimanfaatkan secara maksimal dalam pengelolaan usahatani ubi kayu baik di lahan kering maupun lahan sawah, sehingga produktivitas hasil pertanian masih sangat beragam. Selain itu juga disebabkan oleh kemampuan masyarakat yang masih minim dalam menyesuaikan pola dan mengelola sumberdaya lahan yang tersedia.

\section{METODE PENELITIAN}

Jenis penelitian yang digunakan adalah eksperimen lapangan dengan menggunakan Rancangan Acak Kelompok (RAK) yang terdiri dari 4 perlakuan (Kemas Ali. H, 1998). Tiap unit perlakuan terdiri dari 1 jenis ubi kayu yaitu dari varietas sawah. Adapun desain penelitian adalah sebagai berikut: 
Tabel. 1 Desain Penelitian

\begin{tabular}{|c|c|c|c|c|c|c|}
\hline \multirow{2}{*}{ Perlakuan } & \multicolumn{4}{|c|}{ Kelompok } & \multirow{2}{*}{ Jumlah } & \multirow{2}{*}{ Rata-rata } \\
\hline & I & II & III & IV & & \\
\hline $\mathrm{X}_{0}$ & & & & & $\Sigma Y_{0}$ & $\mathrm{Y}_{0}$ \\
\hline $\mathrm{X}_{1}$ & & & & & $\Sigma Y_{1}$ & $Y_{1}$ \\
\hline $\mathrm{X}_{2}$ & & & & & $\Sigma Y_{2}$ & $\mathrm{Y}_{2}$ \\
\hline $\mathrm{X}_{3}$ & & & & & $\Sigma Y_{3}$ & $\mathrm{Y}_{3}$ \\
\hline Total & & & & & $Y i j$ & $\bar{y}$ \\
\hline
\end{tabular}

\section{Keterangan:}

$\mathrm{X}_{0} \quad=$ Tanpa pemetikan tunas (kontrol)

$\mathrm{X}_{1} \quad=$ Pemetikan tunas 1 Minggu sekali

$\mathrm{X}_{2} \quad=$ Pemetikan tunas 2 Minggu sekali

$\mathrm{X}_{3} \quad=$ Pemetikan tunas 3 Minggu sekali

Yij $=$ Total Nilai pengamatan

y $\quad=$ Rerata Nilai pengamatan

Variabel dalam penelitian ini terdiri dari:

1. Variabel Bebas $(\mathrm{X})$ yaitu pemetikan tunas dengan indikator:
a. $\mathrm{X}_{0}=$ Tanpa pemetikan tunas (kontrol)
b. $\mathrm{X}_{1} \quad=$ Pemetikan 1 Minggu sekali
c. $\mathrm{X}_{2}=$ Pemetikan 2 Minggu sekali
d. $\mathrm{X}_{3}=$ Pemetikan 3 Minggu sekali

2. Variabel Terikat (Y) yaitu hasil panen ubi kayu dengan indikator:

Diameter umbi, Banyaknya umbi kayu yang dihasilkan, Berat umbi kayu pada tiap tanaman/batang.

\section{Tahap Penelitian}

Dalam tahap ini peneliti melakukan kegiatan sebagai berikut:

1. Membersihkan tumbuhan liar yang tumbuh di sekitar pohon ubi kayu yang dijadikan sampel penelitian.

2. Memberi label pada masing-masing perlakuan, dimana masing-masing perlakuan terdiri dari tiga pohon umbi kayu.

3. Setelah itu, langkah selanjutnya adalah memetik tunas ubi kayu pada masing-masing perlakuan, dengan cara:

a. Untuk $\mathrm{X}_{0}$ (kontrol) tanpa pemetikan tunas

b. Untuk $X_{1}$ pemetikan tunas dilakukan1 Minggu sekali

c. Untuk $X_{2}$ pemetikan tunas dilakukan 2 Minggu sekali

d. Untuk $X_{3}$ pemetikan tunas dilakukan 3 Minggu sekali

4. Setelah perlakuan selesai dilakukan maka, Langkah selanjutnya adalahmemanen ubi kayu sertadi hitung diameter, berat, dan banyaknya ubi kayu yang dihasilkan/ pohon. Proses pemanenan dilakukan kurang lebih dalam jangka waktu 3 bulan. 
Pengambilan data ubi kayu per pohon dalam penelitian akan di tabulasi kedalam Tabel 2 berikut:

Tabel 2 Data yang Akan Diperoleh dalam Penelitian

\begin{tabular}{|c|c|c|c|c|c|}
\hline Kelompok & $\begin{array}{c}\text { Diameter } \\
\text { Umbi/batang }\end{array}$ & $\begin{array}{c}\text { Berat Umbi/ } \\
\text { Batang }\end{array}$ & $\begin{array}{c}\text { Banyaknya } \\
\text { Umbi/batang }\end{array}$ & Jumlah & Rerata \\
\hline $\mathrm{X}_{0}$ & & & & & \\
\hline $\mathrm{X}_{1}$ & & & & & \\
\hline $\mathrm{X}_{2}$ & & & & \\
\hline $\mathrm{X}_{3}$ & & & & \\
\hline \multicolumn{2}{|r}{ Jumlah Total }
\end{tabular}

Pada penelitian ini, analisis data yang digunakan adalah dengan menggunakan analisis varians (Anava). Jika ada pengaruh, maka dilanjutkan dengan menggunakan uji lanjut (BNT) berdasarkan nilai koefisien keragaman (KK).

\section{HASIL DAN PEMBAHASAN}

\section{Hasil Pengukuran Panjang Ubi Kayu (cm)}

Proses pemanenan hasil dari pemetikan ubi kayu memperlihatkan bahwa terjadi penurunan hasil panen baik berupa panjang maupun berat karena dampak dari pemetikan tunas ubi kayu. Jelasnya hasil pasca panen ubi kayu dapat di sajikan pada Tabel 3 berikut: Tabel 3 Hasil Pengukuran Panjang Ubi Kayu (cm)

\begin{tabular}{|c|c|c|c|c|c|c|c|}
\hline \multirow[t]{2}{*}{ No } & \multirow[t]{2}{*}{ Perlakuan } & \multicolumn{4}{|c|}{ Kelompok (cm) } & \multirow{2}{*}{$\begin{array}{c}\text { Jumlah } \\
(\mathrm{cm})\end{array}$} & \multirow{2}{*}{$\begin{array}{c}\text { Rerata } \\
(\mathrm{cm})\end{array}$} \\
\hline & & I & II & III & IV & & \\
\hline 1 & $\mathrm{X} 0$ & 29 & 29.6 & 58.7 & 76 & 193.3 & 48.33 \\
\hline 2 & $\mathrm{X} 1$ & 6.3 & 9.8 & 10.1 & 15 & 41.2 & 10.3 \\
\hline 3 & $\mathrm{X} 2$ & 13.2 & 21.8 & 28.5 & 30.8 & 94.3 & 23.6 \\
\hline 4 & $\mathrm{X} 3$ & 7,3 & 28.5 & 47 & 58 & 140,8 & 35,2 \\
\hline & otal & 55.8 & 89,7 & 144,3 & 179,8 & 469,6 & 117,43 \\
\hline
\end{tabular}

Sumber Data: Olahan Data 2014

Panjang ubi kayu yang di peroleh pada pasca panen yaitu jumlah tertinggi berada pada perlakuan $\mathrm{X}_{0}$ dengan jumlah $193.3 \mathrm{~cm}$ dengan rerata $48.33 \mathrm{~cm}$. Sedangkan panjang ubi kayu terendah berturut-turut terdapat pada perlakuan $X_{1}$ yaitu 41,2 cmdengan rerata10,3 cm, X2 yaitu 94,3 cm dengan rerata 23,6 cm dan X3 yaitu 140,8 cm dengan rerata $35,2 \mathrm{~cm}$. Jadi total panjang ubi kayu yang dihasilkan secara keseluruhan adalah $469,6 \mathrm{~cm}$ dengan rerata yaitu $117,43 \mathrm{~cm}$. Untuk mengetahui rerata panjang ubi kayu yang dihasilkan dalam setiap perlakuan maka akan di perjelas dengan grafik berikut: 


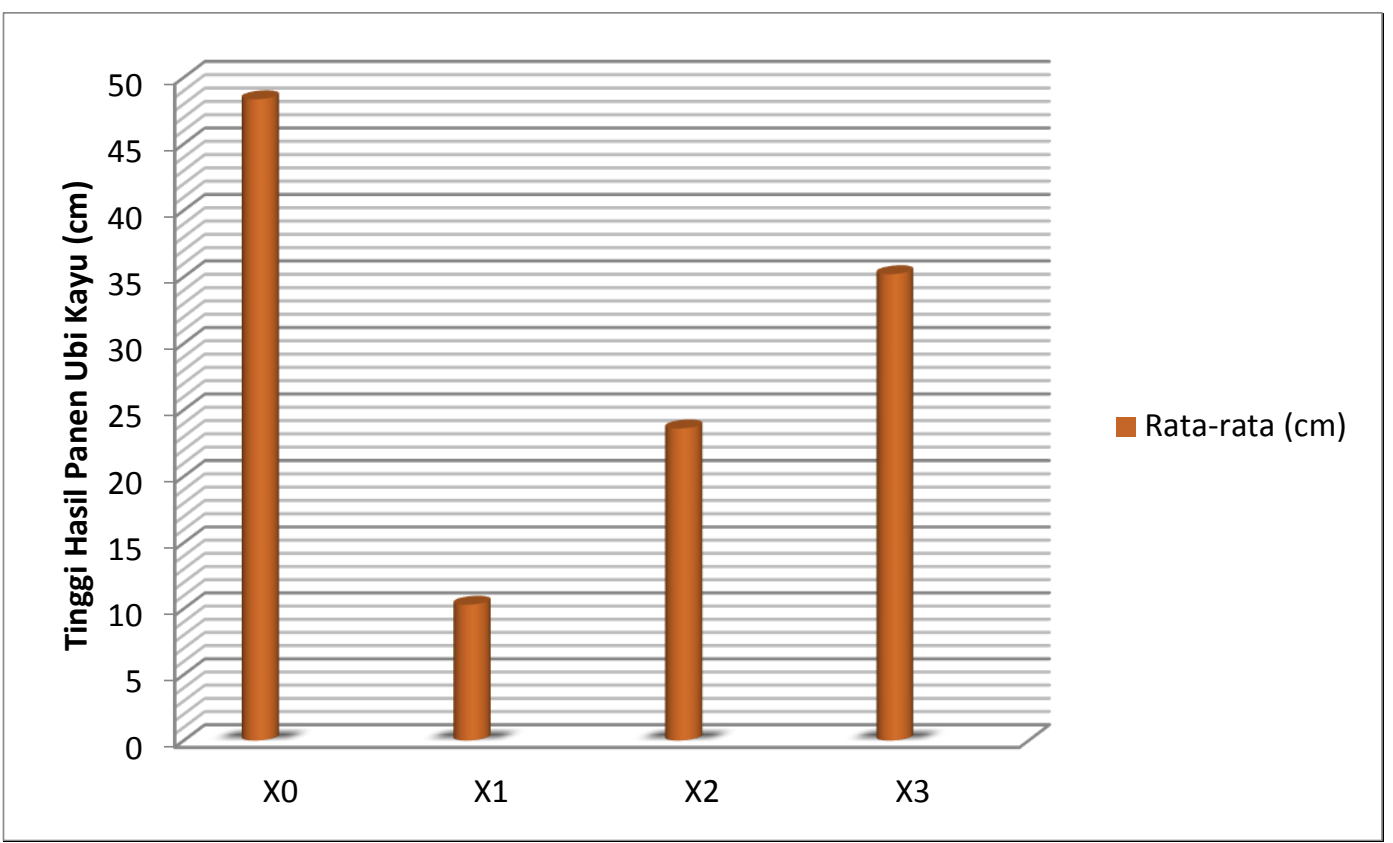

Gambar 1. Rerata Panjang Ubi Kayu padaTiap Perlakuan

Dari diagram di atas, terlihat perbedaan rata-rata ubi kayu yang dihasilkan pada masing-masing perlakuan. Rerata tertinggi berada pada perlakuan X0 dengan jumlah $48,33 \mathrm{~cm}$, dan rerata terendah yaitu perlakuan X1yaitu 10,3 cm, X2 yaitu 23,6 cm dan X3 yaitu $35,2 \mathrm{~cm}$, hal ini terlihat bahwa semakin banyak tunas ubi kayu yang diambil/ dipetik maka semakin menurun panjang ubi kayu, begitu pun sebaliknya apabila tunas ubi kayu tidak dipetik atau jarang di petik maka lebih panjang hasil panen bila dindingkan dengan pemetikan tunas ubi kayu.

\section{Hasil Pengukuran Berat Ubi Kayu (kg)}

Dari hasil pengukuran berat ubi kayu didapatkan bahwa terjadi penurunan yang sangat signifikan, hal ini dapat dilihat pada Tabel 4 berikut:

Tabel 4 Hasil Pengukuran Berat Ubi Kayu (kg)

\begin{tabular}{|c|c|c|c|c|c|c|c|}
\hline \multirow[t]{2}{*}{ No } & \multirow[t]{2}{*}{ Perlakuan } & \multicolumn{4}{|c|}{ Kelompok (kg) } & \multirow{2}{*}{$\begin{array}{c}\text { Jumlah } \\
(\mathrm{kg})\end{array}$} & \multirow{2}{*}{$\begin{array}{c}\text { Rerata } \\
(\mathrm{kg})\end{array}$} \\
\hline & & I & II & III & IV & & \\
\hline 1 & $\mathrm{X} 0$ & 0.6 & 0.7 & 1.7 & 1.9 & 4.9 & 1.23 \\
\hline 2 & $\mathrm{X} 1$ & 0.2 & 0.3 & 0.4 & 0.4 & 1.3 & 0.33 \\
\hline 3 & $\mathrm{X} 2$ & 0.4 & 0.6 & 0.8 & 0.9 & 2.7 & 0.7 \\
\hline 4 & X3 & 0.8 & 0.9 & 1.1 & 1.6 & 4.4 & 1.1 \\
\hline & otal & 2 & 2.5 & 4 & 4.8 & 13.3 & 3.36 \\
\hline
\end{tabular}

Dari tabel di atas, dapat dijelaskan bahwa berat tertinggi pada perakuan A0 denganjumlah4,9 (rerata adalah 1,23 cm), sedangkan jumlah terendah berturut-turut pada perlakuan X1 dengan jumlah 1,3 (rerata adalah 0,33 cm), X2 dengan jumlah 2.7 (rerata adalah 2,7 cm), X3 dengan jumlah 4,4 kg (rerata adalah 1,1 cm), dan total rata-rata berat keseluruhan adalah $3,36 \mathrm{~cm}$. Tinggi-nya berat hasil panen didasarkan pada pemetikan tunas ubi kayu, dimana pemetikan tunas yang dilakuakan terus-menerusakan menurunkan 
berat ubi kayu begitu-pun sebaliknya apa bila pemetikan tunas jarang dilakukan atau tidak sama sekali maka hasilnya justru lebih baik. Untuk mengetahui rerata tinggi berat ubi kayu pada setiap perlakuan maka dapat dilihat pada diagram berikut:

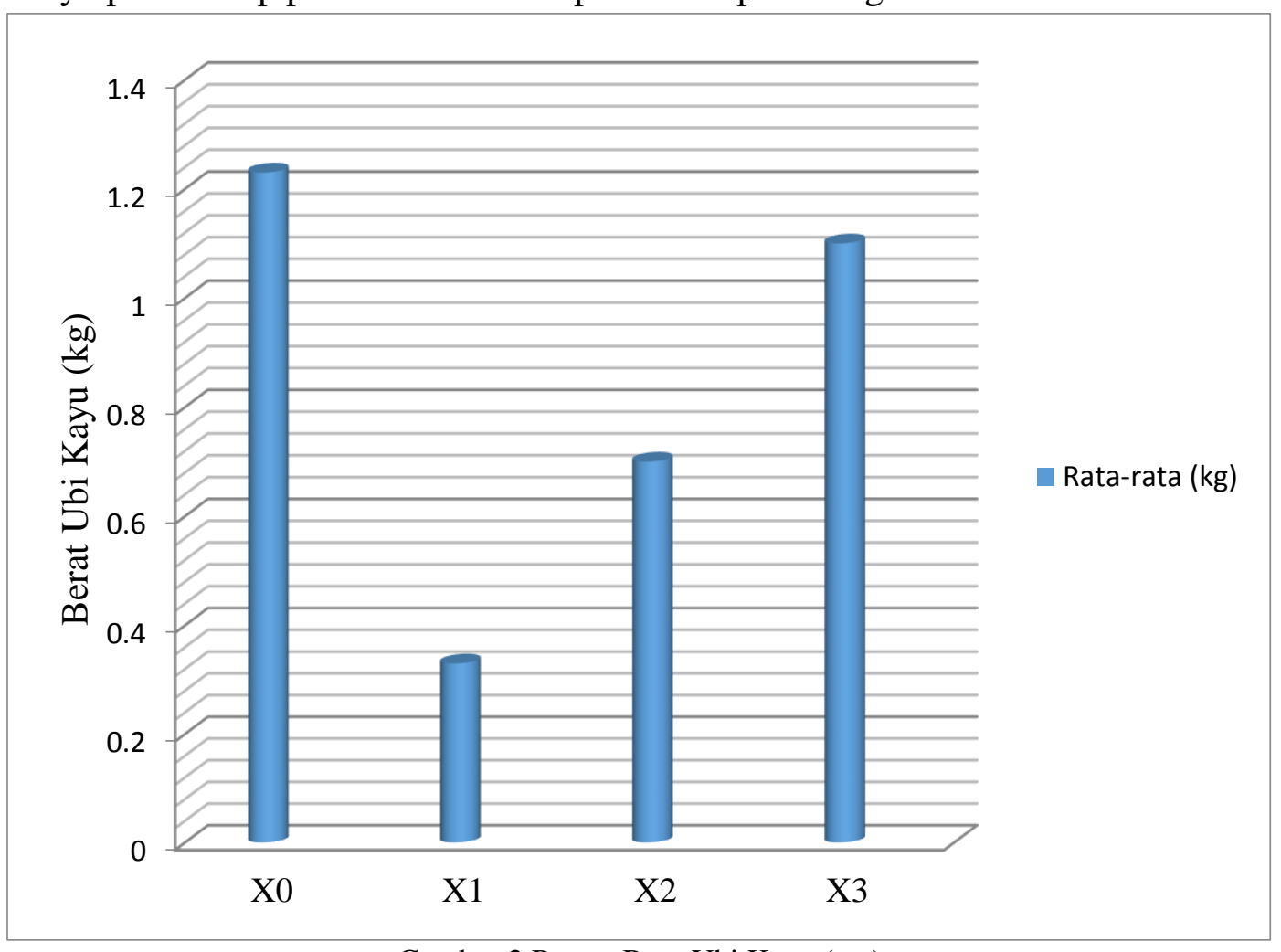

Gambar 2 Rerata BeratUbi Kayu (cm)

Diagram di atas, rata-rata tertinggi berat ubi kayu terdapat pada perlakuan X0 yaitu dengan jumlah $1,23 \mathrm{~cm}$, rata-rata terendah berturut-turut terdapat pada perlakuan X1 jumlah 0,33 cm, X2 jumlah $0,7 \mathrm{~cm}, \mathrm{X} 3$ Jumlah $1,1 \mathrm{~cm}$, dan total rata-rata berat keseluruhan adalah $3,36 \mathrm{~cm}$. Untuk mengetahui ada tidaknya pengaruh pemetikan tunas terhadap hasil panen ubi kayu maka, dilakukan pengujian dengan uji SPSS 15 yang di yaitu uji deskritif, uji anava, dan uji koefisien korelasi.

\section{Uji Statistik Deskritif}

Tabel 5 Uji Descriptive Statistics

\begin{tabular}{|c|c|c|c|}
\hline & Mean & Std. Deviation & $\mathrm{N}$ \\
\hline Jumlah Berat (kg) & 3.33 & 1.646 & 4 \\
Jumlah Panjang (cm) & 117.40 & 64.932 & 4 \\
\hline
\end{tabular}

Sumber Data: Olahan Hasil SPSS November 2014

Uji deskritif di atas, dapat dijelaskan bahwa rata-rata perolehan panjang ubi kayu yaitu 3,33 kg dengan standar deviasi yaitu $1,646 \mathrm{~kg}$ dan rata-rata berat ubi kayu adalah $117,40 \mathrm{~cm}$ dengan standar deviasi 64,932. Hal ini jika dihubungkan dengan pemetikan tunas maka terjadi penurunan hasil panen terhadap berat ubi kayu yaitu sebesar3,33 kg per pohon dan menurunkan panjang ubi kayu sebesar $117.40 \mathrm{~cm}$ per pohon. 


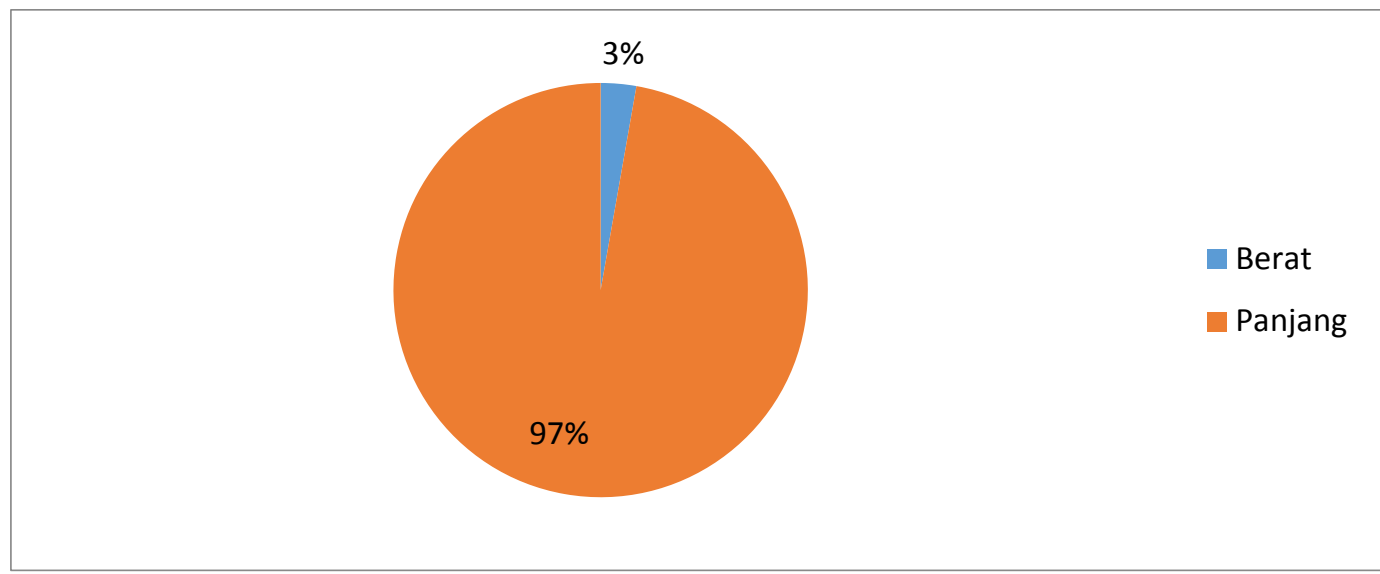

Gambar 3 Hasil Panen Ubi Kayu

Dari hasil uji deskritif didapatkan pengaruh pemetikan tunas terhadap berat ubi kayu yaitu sebesar $3 \%$, dan pengaruh pemetikan tunas terhadap panjang ubi kayu yaitu sebesar 97\%. Dapat dipaparkan bahwa semakin tunas ubi kayu di petik maka terjadi penurunan hasil panen dan begitu pun sebaliknya, apabila tunas ubi kayu jarang dipetik maka terjadi peningkatan hasil panen ubi kayu. Untuk mengetahui besar pengaruh pemetikan tunas terhadap hasil panen ubi kayu serta menjawab hipotesis penelitian maka dilakukan uji anava. Berikut hasil uji anava:

\section{UjiAnava}

Tabel 6 UjiAnova (b)

\begin{tabular}{|c|c|c|c|c|c|c|}
\hline \multicolumn{2}{|c|}{ Model } & $\begin{array}{l}\text { Sum of } \\
\text { Squares }\end{array}$ & Df & Mean Square & $F$ & Sig. \\
\hline \multirow[t]{3}{*}{1} & Regression & 7.767 & 1 & 7.767 & 3.133 & $.022^{(a)}$ \\
\hline & Residual & .360 & 2 & .180 & & \\
\hline & Total & 8.128 & 3 & & & \\
\hline
\end{tabular}

a Predictors: (Constant), Pemetikan Tunas

b Dependent Variable: Jumlah Berat dan Jumlah Panjang

Berdasarkan hipotesis, jika $\mathrm{F}_{\text {hitung }} \geq \mathrm{F}_{\text {tabel }}$ maka $\mathrm{H}_{1}$ diterima atau terdapat pengaruh pemetikan tunas terhadap hasil panen ubi kayu. Dari hasil penelitian, ternyata terdapat pengaruh pemetikan tunas terhadap hasil panen ubi kayu. Menurut Tarigan Istilah faktor penghambat dalam panen ubi kayu sering juga disebut dengan korban produksi, karena faktor produksi atau input tersebut dikorbankan untuk menghasilkan produk. Macam faktor produksi atau input ini, berikut jumlah perlu diketahui oleh seorang petani. Oleh karena itu untuk menghasilkan hasil panen, maka diperlukan pengetahuan hubungan antara faktor penanaman, perawatan (input) dan pasca panen (Anonim, 2014).

Ubi kayu/singkong dalam bahasa latin disebut Manihot esculenta crantz, merupakan tanaman yang banyak mengandung karbohidrat. Oleh karena itu, singkong dapat digunakan sebagai sumber karbohidrat disamping beras, selain dapat pula digunakan untuk keperluan bahan baku industri seperti tepung tapioca. Sampai saat ini sector pertanian umumnya di daerah Maluku belum dapat mensejahterakan petani dan 
memenuhi kebutuhan sendiri, dikarenakan peran ubi kayu dalam perekonomian Nasional khususnya Maluku terus menurun karena dianggap bukan komoditas prioritas, sehingga kurang mendapat dukungan investasi baik dari sisi penelitian dan pengembangan, penyuluhan, pengadaan sarana dan prasarana, serta dalam pengaturan dan pelayanan.

Akibatnya luas areal panen ubi kayu terus berkurang dikarenakan sebagian besar petani ubi kayu beralih profesi atau dengan kata lain mengganti tanaman ubi kayu dengan tanaman lain yang dianggap lebih bermanfaat, sehingga produktivitas ubi kayu tidak meningkat secara nyata. Salah satu penyebabnya adalah belum tepatnya teknologi untuk meningkatkan pendapatan petani ubi kayu. Hal ini dikarenakan sumber daya manusia belum dimanfaatkan secara maksimal dalam pengelolaan usaha tani ubi kayu baik di lahan kering maupun lahan sawah, sehingga produktivitas hasil pertanian masih sangat beragam. Selain itu, disebabkan oleh kemampuan masyarakat yang masih minim dalam menyesuaikan pola dan mengelolah sumber daya lahan yang tersedia.

Melihat kondisi saat ini, ubi kayu yang di nilai mampu dijadikan sebagai bahan pangan alternatif ternyata belum mampu menghasilkan pendapatan optimal bagi petani karena harga jual ubi kayu yang begitu rendah. Sehingga perlu dianalisis bahwa faktor yang dapat mempengaruhi penurunan harga ubi kayu di Provinsi Maluku saat ini. Upaya ini akan berhasil apabila petani sebagai produsen dalam pelaksanaannya mau meninggalkan cara budidaya tradisional dan menerapkan cara budidaya yang dianjurkan, seperti pengolahan tanah yang baik, menggunakan varietas unggul, pemilihan bahan tanam yang tepat, pengaturan jarak tanam yang tepat, pemupukan serta penyiangan dan pertumbuhan (Purwono \& Purnamawanti, 2007).

\section{KESIMPULAN}

Dari hasil penelitian ini maka dapat disimpulkan bahwa terdapat pengaruh pemetikan tunas terhadap hasil panen ubi kayu,dimana nilai $F_{\text {hitung }}=\left\langle\mathrm{F}_{\text {tabel }(0,005)}\right.$.

\section{SARAN}

Dari kesimpulan di atas maka saran dalam penelitian ini yaitu perlu diinformasikan kepada petani bahwa pemetikan tunas akan menurunkan hasil panen ubi kayu.

\section{DAFTAR PUSTAKA}

A.K. Hanafiah. 2011. Rancangan Percobaan TeoridanAplikasi. Jakarta: Raja Grafindo Persada.

Darjanto dan Murjati. 2000. Khasiat, Racun dan Masakan Ketela Pohon. Bogor: Yayasan Dwi Sri. 
Fauzi, A. R. 2010. Induksi Multiplikasi Tunas Ubi Kayu Secara In Vitro. Skripsi. Departemen Agronomi dan Hortikultura, Fakultas Pertanian Institut Pertanian. Bogor

Purwono \& H. Purnamawati. 2007. Budidaya 8 Jenis Tanaman Pangan Unggul. Jakarta: Penebar Swadaya.

R. Prihandana, Hendroko R. 2007. Energi Hijau. Jakarta: Penebar Swadaya.

Rukmana R. 2001. Ubi Kayu: Budidaya dan Pasca Panen. Yogyakarta: Kanisius.

Soekartawi. 2005. Agroindustri dalam Perspektif Sosial Ekonomi. Jakarta: PT Raja Grafindo Persada.

Westby A. 2002. Cassava utilization, storage and small-scale processing. Di dalam Hillocks RJ, Thresh JM, Bellotti AC, editor. Cassava: Biology, Production and Utilization. Diakses tanggal 29 Januari 2014. 